\title{
Pelacakan Gen Sitokrom Oksidase Sub Unit I (COI) DNA Mitokondria Itik Tegal (Anas domesticus) Menggunakan Primer Universal
}

\author{
Sarwo Edi Wibowo ${ }^{1}$, Muhammad Anwar Djaelani ${ }^{1}$ dan Hermin Pancasakti K$^{\mathbf{1}}$ \\ ${ }^{1}$ Jurusan Biologi, Fakultas Sains dan Matematika, Universitas Diponegoro, Tembalang, Semarang 50275 \\ Telp. (024) 7474754; Fax. (024) 76480690 \\ email: sarwo_e_wibowo@yahoo.co.id
}

\begin{abstract}
Currently local ducks are generally quite difficult to find in a big farm in Inonesia, including Tegal ducks. Tegal ducks is one of the genetic resources native to Indonesia with it's advantages in terms of high and large egg production. Conservation and development of local ducks have strived to maintain our existence of Indonesian livestock germplasm. If such information is not superior to native species exist, the opportunity to increase his lead further also getting smaller. Tracking the mitochondrial COI gene DNA of Tegal ducks may underlie the process of an organism's genetic characterization. Information about Tegal duck mitochondrial DNA has not been done. The information obtained can be used for optimization of duck products native to Indonesia both in physiological aspects, phylogeny and genetic engineering. The research method used in this research is tracking COI gene data from Gen Bank with the programs Clustal X and Genedoc. Tracking then continued using universal primers HCO and LCO. The results of the data followed up with the isolation and amplification of COI gene mitochondrial DNA as well as the optimization of PCR conditions. The results showed mitochondrial DNA COI gene Tegal ducks were amplified with primer LCO obtain DNA fragments of length less than $250 \mathrm{bp}$.
\end{abstract}

Kata kunci: duck’s from Tegal, COI gene, mitochondrial DNA

\begin{abstract}
Saat ini umumnya cukup sulit menjumpai itik lokal di peternakan di Inonesia, termasuk itik Tegal.Itik Tegal merupakan salah satu itik sumber daya genetik asli Indonesia dengan keunggulan dalam hal produksi telur yang banyak dan berukuran besar. Pelacakan gen COI DNA mitokondria itik Tegal dapat mendasari proses pelestarian dan pengembangan karakterisasi genetik organisme lokal. Informasi mengenai DNA mitokondria itik Tegal selama ini belum dilakukan, padahal dibutuhkan untuk optimalisasi produk itik asli Indonesia baik dalam aspek fisiologis, filogeni maupun rekayasa genetika.Penelitian diawali dengan pelacakan data gen COI dari Gen Bank dengan program Clustal X dan Genedoc. Hasil olah data ditindak lanjuti dengan isolasi dan amplifikasi gen COI DNA mitokondria serta optimasi kondisi PCR. Hasil penelitian memperlihatkan gen COI DNA mitokondria itik Tegal yang diamplifikasi dengan primer LCO memperoleh fragmen DNA yang memiliki panjang kurang dari $250 \mathrm{pb}$.
\end{abstract}

Kata kunci: itik Tegal, gen COI, DNA mitokondria

\section{PENDAHULUAN}

Indonesia megabiodiversitas dengan kekayaan plasma nutfah yang sangat tinggi. Variasi genetik dalam populasi yang merupakan gambaran perbedaan respon individu-individu terhadap lingkungannya.Plasma nutfah merupakan sumberdaya alam yang penting untuk dilestarikan.Upaya pelestarian dan pengembangan itik lokal akan menentukan keberhasilan program konservasi, pemuliaan dan mempertahankan keberadaan plasma nutfah ternak Indonesia yang telah beradaptasi dengan lingkungan setempat, hal ini pula yang perlu dilakukan pada itik Tegal.

Itik Tegal memiliki keunggulan dalam hal produksi telur yang berkualitas. Di sisi lain ratusan peternak itik di Kelurahan Pesurungan Lor, Kecamatan Margadana, Kota Tegal terancam bangkrut ditahun 2012 dikarenakan naiknya ongkos produksi ternak petelur. Hal ini dapat 
menurunkan minat dalam pemanfaatan itik Tegal sebagai hewan produksi.

Penurunan tingkat pemanfaatan yang lebih lanjut dapat menggeser keberadaan itik Tegal yang merupakan sumberdaya genetik asli Indonesia.Sumberdaya genetik atau plasma nutfah ternak mulai berkurang dengan cepat hampir diseluruh dunia.Selama 15 tahun terakhir, 300 dari 6000 rumpun yang diidentifikasi oleh FAO telah punah.Pemberdayaan plasma nutfah baru bisa dilakukan apabila tersedia informasi yang cukup untuk sifat-sifat yang diperlukan, dengan melakukan karakterisasi (Subandrio, 2006).

Apabila informasi spesies lokal unggul tidak ada maka keragaman genetik juga akan punah sebelum keberadaannya sempat diketahui. Keragaman genetik tidak hanya berguna langsung bagi ternak, keberhasilan pemuliaan ternak juga dapat dipakai sebagai model untuk spesies lainnya (Sponenberg, 2000).

Pelacakan genetik merupakan studi bioinformatika yang melibatkan studi biologis dan studi teknologi informasi. Pengolahan data gen dari sumber yang telah diteliti menggunakan perangkat lunak dapat menunjukkan spesifitas dalam serangkaian proses untuk PCR. Pelacakan gen dapat memiliki spesifisitas yang tinggi. Identifikasi dan karakterisasi gen seringkali diperlukan dalam berbagai percobaan molekuler antara lain isolasi, kloning ataupun mempelajari ekspresinya(Santoso, 2001).

Salah satu sumber informasi karakter genetik dari makhluk hidup adalah DNA mitokondria (mtDNA).Perbandingan urutan basa DNA mitokondria telah digunakan dalam studi genetika populasi dan filogeni bidang kedokteran untuk pelacakan penyakit, pada Diptera, kedokteran hewan dan kepentingan ekonomis (Bajpai dan Tewari, 2010).Informasi yang dikumpulkan dari karakter genetik itik Tegal berupa DNA mitokondria, dapat digunakan sebagai dasar dalam usaha konservasi genetik terhadap itik Tegal dan pada tahap lebih lanjut pada pembuatan bank data. Gen COI merupakan gen dalam mitokondria yang dapat digunakan dalam studi karakter genetik maupun filogeni dari itik Tegal. Ukuran dan struktur dari gen cytochrome oxidase subunit 1 (COI) telah menjadi fokus pada analisis kelompok hewan dan studi evolusi sebagaimanadiperlihatkan pada studi karakter genetik maupun pola-pola evolusi pada bebek (subfamili Anatinae)(Tubaro dan Lijtmaer, 2002),pada itik Peking (Anas platyrhyncos) (Ramirez et al., 1993), pada itik di Philipina (Bondoc, 2012).

Informasi mengenai DNA mitokondria itik Tegal selama ini belum dilakukan, oleh karena itu pelacakan gen COI mt DNA itik Tegal ini dapat menjadi suatu awal dalam menentukan karakter genetik itik Tegal. Hal ini mengingat pula bahwa informasi yang diperoleh dapat dimanfaatkan pada aspek yang berbeda yakni dalam optimalisasi produk itik asli Indonesia baik dalam aspek fisiologis, filogeni maupun rekayasa genetika. Penelitian ini menggunakan primer universal HCO-LCO dalam proses amplifikasi gen COI DNA mitokondria menggunakan PCR pada itik. Aplikasi primer universal dipilih untuk melihat seberapa jauh persamaan dan perbedaan antar itik Tegal dengan itik lain yang telah terkarakterisasi di pustaka. Penelitian ini juga mengunakan itik Semarang sebagai pembanding.

\section{BAHAN DAN METODE Bahan Penelitian}

Bahan penelitian yaitu otot bagian kaki itik Tegal dan itik Semarang, es batu, bufer digesti, Sodium Dodesil Sulfat (SDS), fenol, kloroform, sodium asetat $3 \mathrm{M} \mathrm{pH} 5.2$,etanol $100 \%$, etanol 70 $\%$, bufer Tris EDTA (Etilen Diamin Tetra Asetat) (TE) $\mathrm{pH} 8$, aquades, agarosa, bufer Tris Asam asetat EDTA (TAE), loading dye, Etidium Bromida (EtBr), Primer LCO, Ampli Taq (bufer PCR 10x, dNTPs, enzim Taq polymerase) dan ddH2O.

\section{Pelacakan gen COI mitokondria}

Gen COI dari mtDNA merupakan gen target. Sekuen mtDNA dipakai sebagai sumber data.Sekuen-sekuen ini kemudian dianalisis BLAST untuk menentukan daerah-daerah terkonservasi, dan sekuen nukleotidanya dikonfirmasi. Pelacakan gen COI dilakukan dengan mencari urutan basa dari gen COI hewan yang sekerabat dengan Itik Tegal dan Itik Semarang. Urutan basa dari Archilochus colubris, A. alexandri, Sturnella magna, Centrocercus minimus, Dendragapus obscures, Picoides 
nuttallii, Spheniscus demersus, S.magellanicus, danAnas platyrhynchos diperoleh dari GenBankm.Urutan basa disejajarkan dengan Program ClustalX untuk kemudian dipilih yang memiliki kemiripan lebih dalam basa penyusunnya. Hal tersebut dipilih untuk dasar pelacakan penempelan primer.

\section{Pelacakan Penempelan Primer Universal HCO- LCO Gen COI DNA mitokondria Anas domesticus}

Pelacakan Penempelan Primer Universal ini dilakukan dengan program computer ClustalX dan Gene Doc. Pensejajaran dilakukan dengan ClustalX untuk selanjutnya dibaca hasilnya menggunakan program Gene Doc. Pelacakan ini dilakukan dengan primer $\mathrm{HCO}$ dan LCO, primer tunggal $\mathrm{HCO}$ dan primer tunggal LCO. Hasil pengolahan data dianalisis untuk menentukan proses PCR berdasarkan parameter-parameter yang umum, antara lain jumlah nukleotida, kandungan $\mathrm{GC}$ dan dak terdapat kemungkinan adanya saling komplemen antara basa di dalam satu rantai primer ataupun antara primer yang satu dengan lainnya

\section{Ekstraksi DNA}

Itik yang digunakan untuk penelitian ini berasal dari peternakan bebek di Pesurungan Lor Tegal Barat.Isolasi dan ekstraksi DNA dengan menggunakan Metode Fenol-Kloroform Modifikasi Ausubel et al.,(1995) yang diambil dari bagian paha itik tegal (Anas domesticus). Prosedurnya adalah sebagai berikut :

Otot dari bagian paha itik tegal (Anas domesticus) dipotong dan diambil sebanyak $1 \mathrm{mg}$ kemudian ditumbuk dengan menggunakan mortar dan pastel sampai sampel menjadi halus yang sebelumnya telah disterilisasi dan dimasukkan kedalam pendingin. Penumbukan ini bertujuan untuk memecah membran sel secara mekanik untuk mengeluarkan DNA dari sel. Penumbukan dilakukan pada perlakuan suhu dingin, kemudian ditambahkan bufer digesti sebanyak $6 \mathrm{ml}$ untuk $1 \mathrm{~g}$ sampel.Setelah itu ditambahkan enzim lisozim sebanyak $10 \square$ l. Suspensi kemudian diinkubasi pada suhu suhu $37^{\circ} \mathrm{C}$ selama 1 jam dalam kondisi diapungkan. Suspensi kemudian ditambahkan SDS
10\% sebanyak $1 \mathrm{ml}$ untuk $1 \mathrm{~g}$ sampel.Langkah selanjutnya suspensi dihomogenkan dan di inkubasi pada suhu $50^{\circ} \mathrm{C}$ selama 12 jam, setiap 30 menit sekali dilakukan penggojogan pada suspensi yang telah dibuat.

Suspensi yang telah diinkubasi dan dihomogenkan tersebut, kemudian disentrifugasi pada kecepatan $10.000 \mathrm{rpm}$ selama 5 menit. Tahap selanjutnya supernatan di ambil dengan menggunakan mikropipet dan ditambahkan dengan fenol : kloroform dengan perbandingan 1:1 pada supernatan yang dihasilkan tersebut dan disentrifugasi selama 5 menit pada kecepatan $10.000 \mathrm{rpm}$. Langkah tersebut akan menghasilkan 3 layer. Layer paling atas diambil dan kemudian dipindahkan pada tabung mikrosentrifuga yang baru lalu ditambahkan dengan sodium asetat $3 \mathrm{M}$ $\mathrm{pH} 5,2$ sebanyak $1 / 10$ volume fasa atas yang diambil dan kemudian dihomogenkan. Sampel ditambahkan dengan etanol $100 \%$ sebanyak 2 volume sampel dan kemudian dihomogenkan dan didiamkan pada suhu dingin.Sampel selanjutnya disentrifugasi kembali dengan kecepatan 8.000 rpm selama 5 menit.Pelet yang terbentuk dipindahkan kedalam tabung mikrosentrifuga yang baru kemudian ditambahkan etanol $70 \%$ sebanyak $500 \square 1$ dan kemudian disentrifugasi kembali.Pelet akhir yang terbentuk diambil dan dikeringanginkan selama 24 jam.Pelet yang sudah kering ditambahkan bufer TE $\mathrm{pH}$ 7,6 sebanyak 10$20 \square 1$ dan kemudian disimpan pada lemari pendingin.

\section{Elektroforesis}

Materi genetik berupa DNA hasil isolasi selanjutnya dijalankan pada proses elektroforesis. Elektroforesis DNA dilakukan pada gel agarosa $1 \%$ dan $2 \%$ dengan voltage sebesar 100 Volt selama 20 menit sampai DNA berjalan pada gel agarosa.Proses elektroforesis dilakukan dengan dua pewarna, pewarna pertama menggunakan etidium bromida sedangkan pewarna kedua menggunakan pewarna Good View. Marka yang digunakan adalah marka $\lambda$ Hind III EcoRI dan marka $1 \mathrm{~kb}$ DNA Ladder. Pengamatan dilakukan dibawah $U V$ transilluminator dan didokumentasikan. 


\section{Amplifikasi DNA dengan PCR (Polymerase Chain Reaction)}

Primer yang digunakan adalah primer forward $\mathrm{HCO}$

(3'TAAACTTCAGGGTGACCAAAAAATCA-5'), reverse LCO

GGTCAACAAATCATAAAGATATTGG-3') dan Penggunaan kedua primer tersebut. PCR untuk DNA Anas domesticus dibawah kondisi berikut:

Denaturasi awal $=94^{\circ} \mathrm{C}$ selama 5 menit

Denaturasi $\quad=94^{\circ} \mathrm{C}$ selama 30 detik

Annealing $\quad=54^{\circ} 48^{\circ}$ dan $52^{\circ} \mathrm{C}$ selama 30 detik

Elongasi $=72^{\circ} \mathrm{C}$ selama 45 detik

Elongasi akhir $=72^{\circ} \mathrm{C}$ selama 5 menit

Suhu akhir $\quad=4^{\circ} \mathrm{C}$

Siklus 30X

Hasil PCR kemudian dilihat keberhasilannya pada elektroforesis gel agarosa dengan konsentrasi gel 2\%. Hasil yang terlihat dibawah $U V$ transilluminator kemudian didokumentasikan.

\section{HASIL DAN PEMBAHASAN}

Pelacakan Gen COI perlu dilakukan untuk mengetahui homologi primer universal yang digunakan dengan DNA cetakan dari Itik Tegal dan Itik Semarang. Itik Semarang digunakan sebagai pembanding saat proses elektroforesis. Pelacakan nukleotida gen COI dari hewan sekerabat dilakukan dengan pendekatan bioinformatika menggunakan software yang digunakan untuk membaca urutan basa dari bank data di http://www.ncbi.nlm.nih.gov. Situs ini dipilih karena memiliki data yang cukup lengkap baik dari bank data gen maupun data lainnya dibandingkan dengan sumber yang lainnya.

Primer LCO dan HCO telah banyak digunakan untuk mengamplifikasi gen COI DNA mitokondria hewan oleh beberapa peneliti antara lain Folmeret al.(1994), Liu dan Ma (2011), serta Pawestri (2012), karena dapat memperbanyak urutan basa yang menyandi asam amino lestari pada perlakuan yang berbeda. Hasil pelacakan menggunakan primer universal forward HCO saja pada delapan spesies diatas menunjukkan bahwa primer akan menempel pada urutan basa ke-140 sampai 160 (Gambar 1). Penempelan tersebut bila digunakan untuk mengamplifikasi daerah gen COI sebesar $675 \mathrm{pb}$ dari arah ke 5' ke 3' seharusnya akan memperoleh fragmen gen COI sepanjang sekitar $535 \mathrm{pb}$. Arah penempelan 5' ke 3' pada bagian hilir merupakan arah penempelan yang sesuai untuk primer forward. Penempelan dimulai dari basa ke 140 masih akan memperoleh fragmen gen COI dalam ukuran yang cukup memenuhi untuk keperluan karakterisasi genetik.

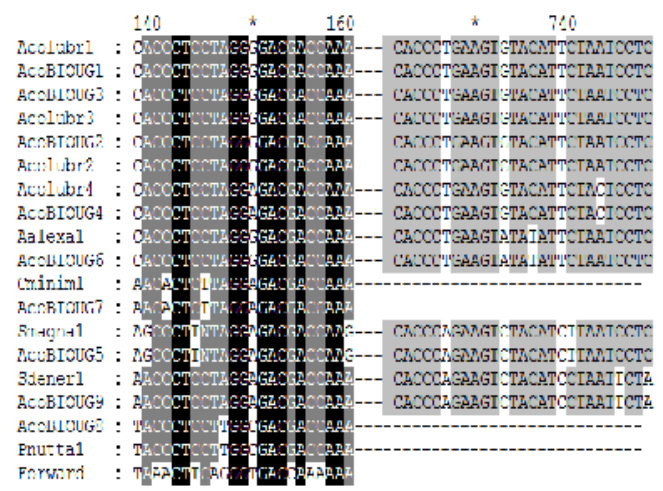

Gambar 1 . Pensejajaran primer forward HCO dengan dataGen Bank

Hasil pelacakan primer universal reverse LCO saja pada delapan spesies menunjukkan bahwa primer akan menempel pada urutan basa dari arah 3' ke 5' pada basa ke-340 sampai 367 pada daerah huluseperti diperlihatkan pada Gambar 2. Hasil pelacakan menggunakan kedua primer forward $\mathrm{HCO}$ dan reverse LCO memperlihatkan bila mereka digunakan bersama maka akan mengamplifikasi fragmen yang sangat pendek yaitu sekitar $227 \mathrm{pb}$.

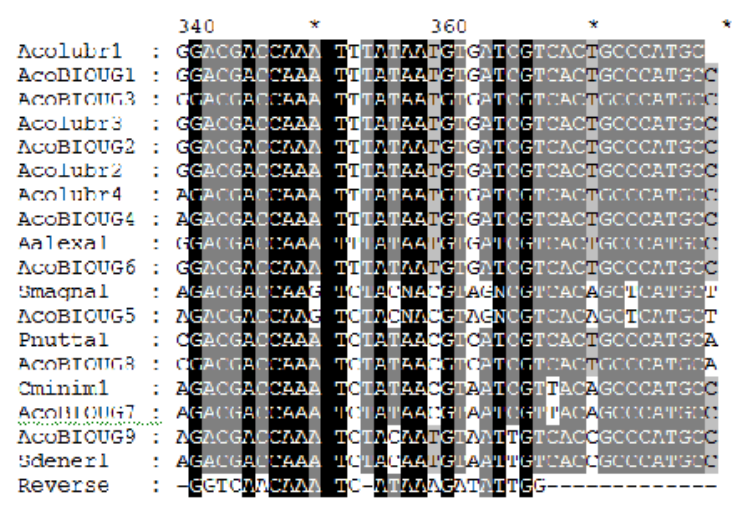

Gambar 2. Pensejajaran primer reverseLCO dengan data Gen Bank 
Analisis tersebut menunjukkan bahwa primer tidak terlalu homolog dengan sampel data, meski demikian primer ini masih dapat digunakan mengingat terdapat cukup basa yang mampu menempel pada primer. Namun demikian maka optimasi dalam amplifikasi diperlukan untuk menghindari terjadinya mispriming, yakni penempelan pada DNA non-target.

Penelitian ini juga melakukan optimasi kondisi PCR berupa suhu penempelan primer dan berdasarkan penelitian rujukan. Selain itu juga dilakukan perubahan jumlah siklus PCR dari dari 36 siklus menjadi 30 siklus. Tahap yang serupa juga dilakukan oleh Connel (2002). Suhu penempelan primer (annealing) pada awalnya menggunakan suhu $48^{\circ} \mathrm{C}$ sesuai dengan penelitian Pawestri (2012) dengan hasil pita DNA tak terlihat. Pada suhu $54^{\circ}$ pita masih smear namun sudah terlihat. Suhu pada proses PCR merupakan faktor penting karena suhu terkait dengan proses penempelan primer pada DNA cetakan. Suhu annealingyang kurang tepat akan menyebabkan adanya penempelan primer pada tempat yang tidak tepat (mispriming) pada daerah target dan nontarget. Akibatnya pita DNA tidak muncul saat elektroforesis.

Selanjutnya dilakukan optimasi suhu penempelan primer dengan menggunakan suhu $52^{\circ} \mathrm{C}$ (Gambar 3. dan Gambar 4). Perlakuan ini merujuk pada penelitian yang dilakukan oleh Kulikova and Kevin (2004) yang dikuatkan dengan pendapat Ausubel et al. (1995) bahwa annealing dapat dilakukan pada rentang suhu 50$65^{\circ} \mathrm{C}$. Tahap ini menunjukkan hasil yang lebih baik dari perlakuan sebelumnya dimana pita dapat terlihat dengan jelas. Hal ini sejalan dengan pendapat Innis dan Gelfand (1990) yang menyatakan bahwa suhu annealing yang ditingkatkan akan mempertinggi perbedaan terhadap pemasangan primer pada daerah yang kurang tepat dan mengurangi pemanjangan dari nukleotida yang tidak tepat pada ujung primer. Suhu annealing yang terlalu rendah akan menyebabkan penempelan primer pada urutan basa DNA yang tidak tepat.

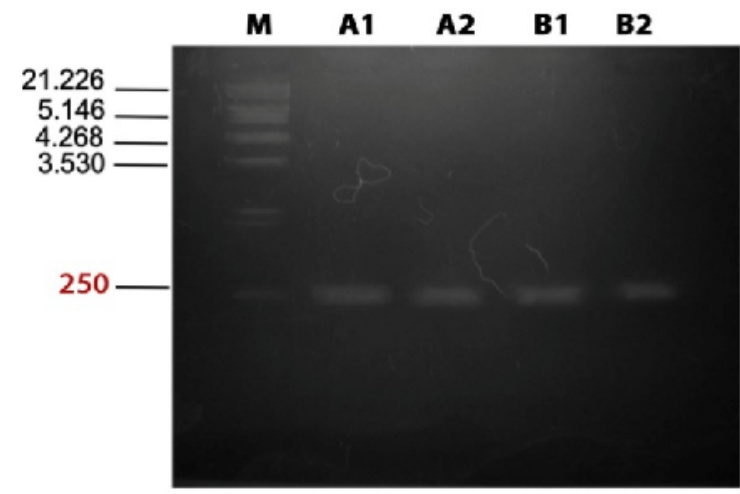

Gambar 3.Visualisasi hasil amplifikasi gen COI itik Tegal pada suhu $52^{\circ} \mathrm{C}$ (gel agarose $2 \%, \mathrm{M}$ $=$ marka $\lambda$ HindIIIEcoRI, Itik Tegal A1 dan A2; Itik Semarang B1 dan B2).

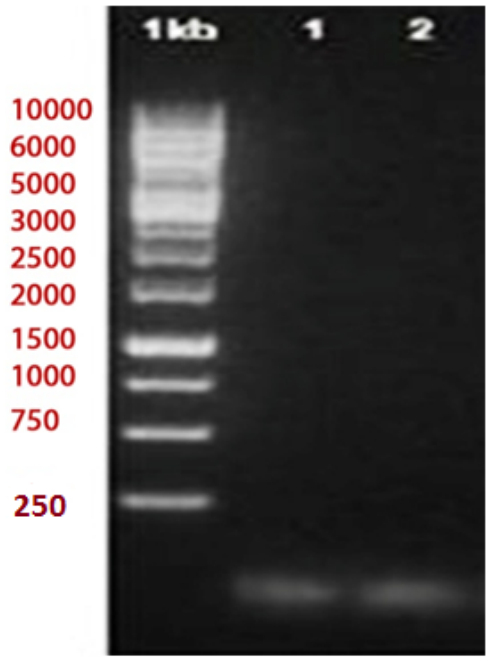

Gambar 4. Visualisasi Hasil amplifikasi gen COI itik Tegal pada suhu $52^{\circ} \mathrm{C}$ menggunakan primer LCO (gel agarose $1 \%, \mathrm{M}=$ marka $1 \mathrm{~kb}$ DNALadder, 1 = Itik Tegal, 2 = Itik Semarang ).

Hasil amplifikasi yang dilakukan memperoleh pita yang berukuran kurang dari target gen COI. Hasil amplifikasi dengan primer LCO saja memperoleh fragmen DNA yang berukuran kurang dari $250 \mathrm{pb}$ (Gambar 4.8). Upaya pelacakan gen yang diperoleh pada penelitian ini selaras dengan penelitian Santoso, 2001. Hasil penelitian yang diperoleh memperlihatkan bahwa penggunaan primer universal HCO untuk memperoleh gen COI pada itik Tegal maupun itik Semarang ternyata kurang 
sesuai. Hasil yang berbeda diperoleh terhadap beberapa jenis ikan dan kerang Haliotis asinina karena penggunaan primer $\mathrm{HCO}$ dan LCO telah memperoleh gen COI sesuai dengan yang ditargetkan. Hasil penelitian dan pelacakan gen juga memperlihatkan implikasi bahwa primer universal selain dipergunakan untuk mengelompokkan spesies yang memiliki gen yang sama juga dapat memperlihatkan perbedaan pada gen yang sama namun spesies yang berbeda. Hasil penelitian juga memperlihatkan bukti laju mutasi yang tinggi pada DNA mitokondria. Perubahan basa pada gen COI DNA mitokondria yang bersifat lestari diperkirakan dapat disebabkan oleh perbedaan genetik yang merupakan akibat isolasi geografis pada itik walaupun DNA mitokondria masih tergolong dalam materi genetik yang bersifat lestari. Meskipun demikian, hal ini masih membutuhkan penelitian lebih lanjut.

\section{KESIMPULAN}

Hasil penelitian yang telah diperoleh menunjukkan pelacakan gen COI DNA mitokondria itik Tegal menggunakan program Clustal $\mathrm{X}$ dan amplifikasi penggunaan primer universal memperoleh hasil yang selaras. Penggunaan primer universal LCO untuk mengamplifikasi gen $\mathrm{COI}$ memperoleh fragmen DNA berukuran kurang dari 250 pasang basa yang menunjukkan bahwa gen yang teramplifikasi merupakan fragmen parsial.

\section{DAFTAR PUSTAKA}

Ausubel, F.M., R. Brent, R. E. Kingston, D. D. Moore, J. G. Seidman, J. J. Smith, dan K. Struhl. 1995. Current protocol in moleculer biology Vol.I.John Willey and Sons. Canada. Hal 110-200.

Bajpai, N. dan R. R. Tewari. 2010. Mitochondrial DNA Sequence-Based Phylogenetic Relationship Among Flesh Flies of The Genus Sarcophaga (Sarcophagidae: Diptera). Department of Zoology, University of Allahabad, India. Hal 89-110.

Bondoc, O. L. 2012. Genetic Diversity and Relationship of Common Poultry Breeds and Strains (Class Aves) in the Philippines Based on the Cytochrome C Oxidase I (COI) Gene Sequence, Submitted (08-JUN-2012) Animal and Dairy Sciences Cluster, College of Agriculture, University of the Philppines Los Banos, ADSC,
CA, Philippines. Hal 300-330.

Connell, Joe. 2002. RT-PCR Protocols: Methods in Molecular Biology. Department of Medicine, National University of Ireland, Cork, Irlandia. Hal 90-110.

Folmer, O., M. Black, W. Hoeh, R. Lutz, dan R. Vrijenhoek. 1994. DNA Primers for amplification of Mitochondrial Cytochrome C Oxidase Subunit I for Diverse Metazoan Invertebrates. Molecular Marine Biology and Biotechnology.Hal 294-299.

Innis, M. A. dan D. H. Gelfand. 1990. Modified after optimizing of PCRs Protocols: A Guide to Mrthodes and Applications. Academic Press, San Diego.Hal 10-15.

Kulikova, V. dan M. K. G. Kevin. 2004. Asymmetric Hybridization and Sex-biased Gene Flow Between Eastern Spot-billed Ducks (Anas zonorhyncha) and Mallards (A. platyrhynchos) in The Russian Far East. Institute of Biology and Soil Sciences, Far East Branch, Russian Academy of Sciences. Hal 930-949.

Liu, D., dan J. Ma. 2011. The Information System for DNA Barcode Data System and Computational Biology-Bioinformatics and Computational Modeling Network Information Center. Institute of Microbiology.Chinese Academy of Science. Hal 470-500.

Pawestri, N. S. 2012. Kekerabatan Ikan Gelodok (Periophthalmus sp), Ikan Ploso (Glossogobius sp), dan Ikan Beloso (Oxyurichthys sp) dari Pantai Morosari Demak dengan Penanda Gen COI DNA Mitokondria. Universitas Diponegoeo. Semarang. Hal 20-40.

Ramirez V, P. Savoie, R. Morais. 1993. Molecular Characterization and Evolution of a Duck Mitochondrial Genome.J Mol. Hal.296-310.

Santoso, D. 2001. Pengembangan pelacak DNA spesifik gen melalui bioinformatika: Indentifikasi gen penyandi protein biji $21 \mathrm{kDa}$ pada kakao UAH Indonesia. Unit Penelitian Bioteknologi Perkebunan. Bogor.Hal 10-17.

Sponenberg, D. P. 2000. Genetic Resources and Their Conservation.CABI Publishing. UK. Hal 387410.

Subandrio. 2006. Konservasi Sumberdaya Genetik Ternak: Pertimbangan, Kriteria, Metoda dan Strategi. dalam Lokakarya Nasional Pengelolaan dan Perlindungan Sumber Daya Genetik di Indonesia: Manfaat Ekonomi untuk Mewujudkan Ketahanan Nasional. Pusat Penelitian dan Pengembangan Peternakan. Bogor. Hal 200-220. 
Tubaro, P. dan D.A. Lijtmaer. 2002. Hybridization Patterns and The Evolution of Reproductive Isolation in Ducks. División Ornitología, Museo Argentino de Ciencias Naturales 'Bernardino Rivadavia' Buenos Aires, Argentina. Biological Journal of the Linnean Society.Hal 197-200. 